\title{
Maxim Gorky's Mother through the Lens of Marxist- Feminism
}

\author{
Dr.Neelam Bhardwaj \\ Assistant Professor, S.C.D. Govt. College, Ludhiana
}

\begin{abstract}
Maxim Gorky's Mother is an influential piece of propaganda about the revolutionary spirit of an old lady who is the mother of only one activist Pavel. But when her son is imprisoned, she works wonderfully for his revolutionary cause and becomes the mother of all the other activists as well as the whole revolution. It is a heart moving account of the miserable condition of workers who work hard but get no reward for that and pass the whole life from hand to mouth. It pushes them to the ignoble path of drinking and making violent clashes. Gorky was an optimistic novelist who does not stop at pointing out the problem but shows the positive solution to the problem too. Mother is truly a Marxist-Feminist novel in a true sense. Mother presents broad and generalized picture of Nilovna \& the working class against capitalists. This paper is a humble effort to trace the influence of Karl Marx and Engles on the novel especially the application of Marxist-Feminist theory.
\end{abstract}

Keywords: Marxism, Feminism, Capitalists, Society, Mother

The whole world is ours! The world is for the workers! For us there is no nation, no race. For us there are only comrades and foes.....We are all children of the workers- the great, invincible idea of brotherhood of the workers of all the countries over the earth. This idea grows, it warms us as much as the Sun; it is a second Sun in the heaven of Justice, and this heaven resides in the workingman's heart. Whoever he be, whatever his name, a socialist is our brother in spirit now an always, through all the ages to come! (Gorky : Chapter -four )

These words are spoken by Pavel, the positive hero, of Maxim Gorky's immortal classic novel Mother which is regarded as the best novel on workers' movement. The novel brings to light the fundamental fact that no revolution succeeds without active support of housewives. Mahatma Gandhi succeeded in running his non-violent movement for India's freedom when even women and children began to take active part in it. The title of the novel suggests that mothers of all such revolutions are not the young but the old women whose whole life become a tale of tears. They become the inspiration and motivating force of all revolutions. This novel is about the pre -revolution proletariat of Russia and focuses on the role of women played in the struggle of the Russian working class on the eve of the Revolution of 1905.

Maxim Gorky was the pen name of Alexi Maximovich .Gorky means 'the bitter one' in Russian language. This name reflected his disappointment with life in Russia and determination to speak the bitter truth in front of the entire world. He is widely recognized as one of the most popular writers as well as a symbol of the socialist movement in Russia. Despite the efforts of the sensors, his works were widely distributed not only among the intellectual community but also the working class. His contemporary and even later critics have argued over the artistic merit of Gorky's work, but there is, no doubt, that he was an extremely significant literary and public figure in the period following the Revolution of 1905. There is certain inwardness about the way in which Gorky writes about the travails of the lower classes, as he invariably speaks from personal experience. Though Gorky's Mother is focussed exclusively on the revolutionary movement, Mother can easily be read as a novel that prescribes a definite model for social development.

Marxist- Feminism is the theory which focuses on the eradication of the industrialist society as a mode of liberating women. The Marxist- Feminist's ideology sprung from Engles in his 'The Origins of the Family, Private Property and the State' (1884). In his book, he explained that women's inferiority is not a result of her biological nature but of social affairs. The Marxist Feminists believe that the one way for women to emancipate themselves is through the abolition of the capitalist society. 
Women can only be truly free, truly equal with men, truly feminists if they stand on the grounds of socialism and working class. The liberation of men and women from the bondage of the inhuman capitalist society is the true strength of the Marxist- Feminist ideology.

From the beginning of the novel to the end, the viewpoint of Pelagea Nilovna has been used by Gorky to reflect on the state of things in the pre- Revolution period. This viewpoint is one of the most important factors to consider, if not the most important, in discussing the full meaning of the novel. Other factors such as Pelagea Nilovna's occupation, psyche, past, and even her role to the revolutionary movement are of equal importance.

Pelagea Nilovna is a naive woman, in the beginning of the story, at least. Her husband, Michael Vlasov, was a gloomy man who earned little. Every holiday, he used to beat somebody, and everyone disliked and feared him. More than one unsuccessful attempt was made to beat him. People were afraid of his eyes. He was honest and hardworking and did not flatter the supervisor; it was the cause of his little earning. When Pavel, his son, was a boy of fourteen, he warned his father not to touch him. His father looked at him and smiling said to his wife: "Don't ask me for money any more .Pasha your son will feed you now" (Gorky: Chapter -one). From that time, for three years, until his death, he did not notice, and did not speak to his son. Her story actually started when her husband died, making her son, Pavel, the new head of the family. Since Pavel tried to fight his father, the responsibility of making a living for his mother was transferred to him. She had no work. She was the picture of the exploited female proletariat.

Not long after the tragic death of Michael Vlasov, Pavel started to exhibit a different set of habits and behaviour. She became an unfortunate mother because her son cared a fig for her. Just two weeks after the death of his father, Pavel came home so much drunk that he could not even walk steadily. He shouted at his mother for food but the mother rebuked him in a sad and affectionate voice. He wanted to smoke too and asked her to give him father's pipe. It was the first time, he had been drunk. The mother asked in a soft voice: "What sort of a bread giver will you be if you begin to drink? He answers: 'Everybody drinks'. She remarks: 'But don't you drink. Your father drank; he made enough misery for me .Take pity on your mother, then, will you not?" (Gorky: Chapter-two). Pelagea Nilovna did not make any complaint but sighed and thought that he was right. She knew that these workers have no other place for recreation except this tavern. Nevertheless she said that he should not drink. His father drank and he made enough misery for her. He should take pity on his mother. Tears slowly trickled down her cheeks. He requested her not to cry. She felt helpless and began to pray in silence after kneeling before the sacred image upon the wall. The prayer offered by her proved fruitful and Pavel gradually began to avoid the beaten path trodden by all. His attendance at parties reduced. On holidays, he always returned home dignified. He began to bring books home with him. Sometimes he copied a passage on a piece of paper. On holidays, he remained absent from home from morning to late night. She knew he went to the city. Sometimes, she thought perhaps he might become interested in a girl. Again it occurred to her that such could not be the case because to go about with girls, money is the main issue and he used to hand over almost all his earnings to the mother. Nilovna was curious about Pavel's books. He replied that he read forbidden books to get the real situation of the workingmen: "I am reading forbidden books. They are forbidden to be read because they tell the truth about our- about workingmen's life" (Gorky: Chapter-two). She asked why he took that danger to him. He raised his head, looked at her, and said in a low and calm voice: "I want to know the truth" (Gorky: Chapter-two). He reminded the mother her position as well as the sufferings she faced in life. He claimed she knew no joys. She listened and shook her head sorrowfully in a mechanical way, feeling as if something new and unknown was going to happen to her. She wanted to warn him: "My dear what can you do? People will crush you. You will perish, my son!" (Gorky: Chapter-two). But it was pleasant to her to listen to his speeches. With this, Pelagea Nilovna also began to undergo a change. She was unaware that her role in the society was also changing gradually. Being the mother of the most intelligent and well-spoken leader of the revolutionists, she was supposed to be supportive if not an active member in the movement. Yet during the early period of her discovery, one can see her resistance to the ideology. This is not far-fetched, because she was already an old woman whose set of values and beliefs had already been decided. Only a miracle could have possibly changed her beliefs. And, that miracle was her love for her son. She embraced the ideology her son loved not because she was forced to, but because slowly she, too, had learned the philosophy her son wanted to share with the world. Her active co-operation made the movement forceful. She treated other workers like her own son and assumed as if she were the mother of all. She loved all of them. She made 
stockings for Natasha. However ,like what the Khokhol, Pavel's close friend, had said, Pavel has a great way with words -but he lacks one thing that fails to convince the masses- the heart. He could never understand the meaning behind it. And somehow, the novel seems to imply that the missing 'heart' of the socialist movement is with the 'mother'.

The development of the character of Pelagea Nilovna seemed to imply that the women should take up different roles in their struggle for their belief. Gorky has shown that not only the men should take up roles in the revolution, but that women, too, regardless of their age, should contribute to the success of the movement. She became active in the movement when Pavel was arrested under the charge of distributing forbidden literature in the factory. The mother understood that she could be useful to her son, and assured them to manage it herself. Marya would be her assistant. She had to earn her living. She would carry dinners to the factory. It was evident to her that if the leaflets should continue in the factory, the authorities would be forced to recognize that it was not her son who distributed them. She did it successfully. When mother started giving the pamphlets secretly to the people in the factory, she also developed a fine understanding of the ideology, her son was fighting for.

This understanding was very crucial, because many have joined the socialist movement without really understanding why. With Pelagea Nilovna's naivety, people had identified themselves with her and with her understanding, they understood as well.

Pelagea Nilovna became an activist on the first of May. Pavel waved the flag. He shouted: "Long live the workers!" (Gorky: Chapter-nineteen). On hearing this, an officer jumped up to Pavel, snatched the flag pole and shouted to drop it. A few soldiers jumped to the front. Pavel was arrested and bade goodbye. The mother saw the flag pole broken into two parts with a piece of red cloth on one of them. The mother repeated the song of revolution: "Our march is to join our suffering comrades." (Gorky: Chapter-nineteen). She cried out that they are all dear and good people. They should open their hearts and look around without fear. They should support children who were going for the truth with honesty. They had devoted themselves to the sacred cause. All claimed she was speaking God's words and they should listen to her. Having around at the gate of her house, she turned to them and leaning on the fragment of the flag pole, paid them thanks. For the movement, she left the village for the city. Nikolay pointed out that Sofya should undertake the distribution of newspapers with the mother. Early in the morning, the mother and Sofya appeared poorly clad in worn skirts and blouses, with bags on their shoulders, and canes in their hands. They visited the place at the distance of about fifty miles and distributed books. The distribution of literature had become the occupation of the mother. Several times a month, dressed as a nun or a hawker of laces or small linen articles, as a rich merchant's wife or a religious pilgrim, she rode or walked about with a bag on her back everywhere, in the trains, in the steamers, in hotels and inns. She helped prisoners in making a safe escape. Pelagea Nilovna's heroic struggle becomes an inspiring example to all activists. She was moved by Pavel's statement in the court. All decided to publish and distribute it in the public. The mother helped in getting it printed and filled the bundles in a bag. The climax of the novel is not placed in the middle but in the end where we see Pelagea Nilovna fighting with a spy as she demands a right to disseminate her son's speech. When the mother saw that the papers were being snatched up, she hid them in breasts and pockets. She spoke, snatching bundles of papers from the bag and throwing them right and left. Back of the crowd, the mother noticed the spy and two policemen. The mother fell on the ground when she received a blow on the chest. She was arrested and was taken away. She was pushed in the neck and the back, beaten about the shoulders, on the head. She called them poor, sorry creatures who wanted to bury the truth. This is symbolic, though also socialist-realist. It was her dignity that raised her to the height of Jesus Christ.

The novel does not only show Pelagea Nilovna as the empowered woman but also shows Natasha, Sasha, Ludmila and Sophia. Natasha and Sasha are from the upper class, yet their characters show that their hearts belonged to the proletariat and the socialist movement. In a way, this also shows that the only way for a revolution (not only a socialist revolution but also a feminist revolution) to succeed is the female bourgeoisies' readiness to surrender their property.

The female characters who have left their mansions and plantations to help the movement and join the proletariat indicate Gorky's belief and glorification of the Marxist -feminism as well. Unlike Pelagea Nilovna, who had nothing in the beginning of the story, women who are supposed to have everything are presented as if they had nothing, and discovered their worth and dignity only through their several acts of assistance to the leaders of the revolution. 
Symbolically, Pelagea Nilovna can also be Mother Russia herself. Before the 1917 revolution, she had never accepted the idea of communism. However, slowly she learned the ideology that her children all over Russia were fighting for. She never totally realized that she was already accepting the ideology within her. And in the long run, we see Mother Russia embracing the ideology and becoming the 'mother' to all her socialist children.

The novel is, indeed, an aesthetically written work, a perfect example of 'socialist realism' and is usually considered to have the first socialist realist novel. Marxism should not be the only approach used in reading the text. One should always remember that the hero is a woman, and the novel is entitled Mother. Therefore, there is some justification for reading this novel from the perspective of Marxist- Feminism.

\section{REFERENCES}

Barry, Peter. Beginning Theory: An Introduction to Literary and Cultural Theory. UK: Manchester University Press, 2008.Print.

Engles,Friedrich. The Origins of the Family, Private Property and the State. New York: Penguin Books Limited, 2010.Print.

Gorky, Maxim. Mother. Mumbai: Jaico Publishing House, 2002.Print.

Magill, Frank N. Masterplots, New York: Salem Press, 1949. Print.

\section{AUTHOR's BIOGRAPHY}

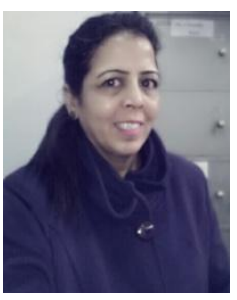

Dr. Neelam Bhardwaj, is an Assistant Professor in the Post-Graduate Department of English, S.C.D. Govt. College, Ludhiana, Punjab which is affiliated with Panjab University, Chandigarh. She has presented a number of papers at various National and International Seminars and Conferences. She has also to her credit many research papers which are published in edited anthologies as well as International Journals of great repute. She is in the Editorial Board of two International Journals. Her areas of interest are Indian Writings in English, American Literature, World Literature, Gender Studies, Post-Colonial Writing, Diasporic Literature, and British Literature. 